\title{
Babad Banyumas Versi Wirjaatmadjan dan Teks-Teks Transformasinya
}

\author{
Sugeng Priyadi \\ Universitas Muhammadiyah Purwokerto \\ Email : sugengpriyadi_5@yahoo.co.id
}

\begin{abstract}
The Babad Banyumas of Wirjaatmadjan version includes texts prose which was written by Patih Raden Arja Wirjaatmadja. This research is based on the Javanese text of manuscript which could be original work of Patih Purwokerto. The tradition of Babad Banyumas of Wirjaatmadjan version is written continuosly so that this manuscripts is available in Banyumas society. There are manuscripts which have been translated, typed, printed, and even rewritten into Javanese letters again. In the processes of writing those manuscripts, the transformation texts happens. The text of the transformation from the work of Wirjaatmadja bring about new Babad Banyumas versions. At last, Babad Banyumas of Wirjaatmadjan version is very populair in the Banyumas society as history book or 'babad baku'.
\end{abstract}

Keyword: The Babad Banyumas of Wirjaatmadjan version, transformation, history book.

Abstrak. Artikel ini mempelajari kebijakan/regulasi negara dan dampaknya masyarakat dan institusi pengelolaan wakaf di Indonesia. Artikel hasil penelitian ini menggunakan pendekatan kualitatif deskriptif dengan teknik pengumpulan data menggunakan observasi dan dokumentasi. Kebijakan atau regulasi negara dalam pengelolaan wakaf di Indonesia telah dimulai sejak pemerintahan kolonial Belanda. Wakaf menjadi institusi keuangan Islam yang ditandai dengan berdirinya Rad Agama atau Pengadilan Agama (priesterrad) berdasarkan staatsblad Nomor 152 Tahun 1882. Pengakuan Belanda tersebut berdasarkan penyelesaian hukum Islam yang diajukan masyarakat ke Mahkamah Syar'iyyah (Peradilan Agama Lokal), namun dalam penerapannya antara satu daerah dengan daerah lainnya berbeda-beda. Pasca kemerdekaan terdapat beberapa peraturan pemerinah mengenai wakaf, salah satunya Peraturan pemerintah Nomor 28 Tahun 1977 tentang Perwakafan Tanah Milik yang hanya mengatur mengenai perwakafan tanah saja dan penggunaannya hanya terbatas untuk kegiatan sosial-keagamaan. Namun, pasca berlakunya UU No. 41 Tahun 2004 tentang Wakaf menyebabkan pengelolaan wakaf menjadi lebih variatif dan kreatif termasuk adanya wakaf uang. Dampak kebijakan negara terhadap masyarakat/institusi pengelola wakaf dalam pengelolaan wakaf di Indonesia menyebabkan pengelolaan wakaf harus dilakukan secara kelembagaan dan bersifat produktif. Wakaf uang dapat dikelelola untuk investasi yang memberikan banyak manfaat kesejahteraan dan kemaslahatan terhadap masyarakat, sehingga menjadi salah salah satu indikator pengelolaan wakaf secara produktif. Selain itu, penguatan pengelolaan wakaf yang dilakukan oleh organisasi sosial-keagamaan, Badan Wakaf Indonesia (BWI), dan Lembaga Keuangan Syariah Penerima Wakaf Uang (LKS-PWU) dilakukan dengan memberikan pemahaman orientasi keuntungan, regulasi, supervisi, dan orientasi publik.

Kata kunci: Babad Banyumas versi Wirjaatmadjan, transformasi, buku sejarah. 


\section{PENDAHULUAN}

Babad Banyumas merupakan identitas etniskultural masyarakat Banyumas yang muncul dari masa lampau yang telah dijalani bersama ratusan tahun yang lalu sebagai unit kesadaran historis (Abdullah 1985: 14). Kesadaran historis masyarakat Banyumas tampak pada teks-teks Babad Banyumas, khususnya versi Wirjaatmadjan, yang berfungsi sebagai buku sejarah yang dikenal secara luas oleh masyarakat Banyumas karena mengalami proses penyalinan secara terus-menerus sehingga ia tampak sebagai tradisi babad yang terbuka (Sulastin-Sutrisno 1994: 70). Selanjutnya, versi Wirjaatmadjan mendapat tanggapan pembaca dalam bentuk teks-teks transformasinya. Penelitian Babad Banyumas terdahulu menunjukkan bahwa ada empat belas versi, yaitu (1) Babad Banyumas Kalibening (gancaran), (2) versi Mertadiredjan (tembang), (3) versi Jayawinata (tembang), (4) versi Adimulya (gancaran), (5) versi transformasi teks Mertadiredjan (gancaran), (6) versi PRBN (gancaran), (7) versi Banjarnegara (tembang), (8) versi Kasman Soerawidjaja (gancaran), (9) versi Wirjaatmadjan (gancaran), (10) versi Oemarmadi \& Koesnadi (gancaran), (11) versi Panenggak Widodo-Nakim (gancaran), (12) versi Danuredjan (tembang), (13) versi Danuredjan (gancaran), dan (14) versi keluarga baru (gancaran) (Priyadi 1997a: 232; bdk. 2000b: 126).

Penelitian terhadap teks-teks Babad Banyumas baru dilakukan pada versi Mertadiredjan (teks Tedhakan Serat Babad Banyumas) (Knebel 1901, bdk. De Graaf 1985, Pigeuad \& De Graaf 1985, Priyadi 1990, 1996, \& 2000a) dan versi Banjarnegara (Babad Wirasaba Kejawar) (Priyadi 1993, bdk. Behrend \& Titik Pudjiastuti 1997). Penelitian terhadap versi-versi yang lain belum dilakukan. Pemilihan versi kesembilan, yaitu versi
Wirjaatmadjan dipandang memiliki gejala tekstual yang menarik karena teks tersebut berfungsi praktis sebagai buku sejarah Banyumas. Di samping itu, teks tersebut juga penting diteliti karena berkaitan dengan teks-teks transformasinya. Penelitian terhadap versi Wirjaatmadjan dapat menjelaskan kesinambungan antara teks tembang (versi Banjarnegara) dengan teks prosa (buku sejarah Banyumas) beserta teks-teks transformasinya.

\section{METODE}

Filologi tradisional bertujuan memulihkan teks sedekat-dekatnya dengan teks aslinya melalui perbandingan teks yang diteliti dan menyusun silsilah teks atau stema (Teeuw 1988: 264). Di sini, peneliti tidak bermaksud menyusun stema karena tradisi teks yang diteliti menunjukkan adanya gejala kontaminasi teks yang berasal dari tradisi lain. Dengan demikian, metode stema tidak diterapkan, tetapi metode ini tidak diabaikan dalam penelitian ini. Naskah yang memuat teks tradisi lain menunjukkan adanya penyimpangan. Ada satu naskah cetakan yang melakukan penyimpangan dengan memberikan angka-angka tahun yang dihubungkan dengan suatu peristiwa.

Penyimpangan teks dalam filologi modern dipandang sebagai kreasi. Oleh karena itu, variasi tersebut dihargai dan ditetapkan sebagai pembanding teks variabel. Teks variabel ditetapkan berdasarkan teks yang tertua dalam huruf Jawa dengan menggunakan metode landasan (Sulastin-Sutrisno 1994: 67). Penetapan teks variabel tersebut didasarkan atas relevansinya dengan studi resepsi, khususnya dalam mencermati teks-teks transformasi yang dihasilkan masyarakat Banyumas.

Secara diakronis, setiap teks senantiasa mendapatkan tanggapan pembaca secara terus-menerus dalam proses konkretisasi. Karya sastra adalah balasan atau jawaban 
atas tuntutan-tuntutan yang diajukan oleh situasi sejarah dan sejarah sosial pada masa tertentu (Teeuw 1988: 192). Dengan demikian, proses pemaknaan atau konkretisasi teks yang baru dapat dibaca dalam kaitan atau pertentangannya dengan teks-teks lainnya (Culler 1981: 103).

Prinsip intertekstual sebagai teori pasca-strukturalisme yang dikembangkan oleh Julia Kristeva adalah usaha pembatasan dan pemungkiran terhadap prinsip otonomi karya sastra (Teeuw 1988: 145). Prinsip ini menyatakan bahwa penciptaan setiap teks tidak pada situasi kosong, melainkan berdasarkan teks-teks terdahulu (Teeuw 1988: 145, Eagleton 1988: 152). Jadi, tidak ada sebuah teks pun yang benar-benar mandiri. Di sini, tidak ada orisinalitas dalam teks, atau tidak ada teks yang pertama. Yang ada hanyalah penciptaan kembali. Penciptaan kembali teks dalam bentuk yang berbeda bahasa, jenis, dan fungsinya merupakan gejala terjadinya transformasi teks. Terwujudnya teks yang baru dihasilkan berdasarkan pembacaan, pemahaman, dan penafsiran pembaca (Wiryamartana 1990: 10).

Penelitian ini melalui metode filologi dan sastra. Metode filologi ditempuh dengan cara membandingkan teks-teks Babad Banyumas versi Wirjaatmadjan sehingga dapat dipilih teks individual sebagai dasar terbitan teks dan objek penelitian. Perbandingan itu menunjukkan bahwa ada satu naskah dari versi tersebut yang mendapat pengaruh dari buku sejarah yang mendasari lahirnya teks-teks transformasi. Penetapan teks sebagai objek penelitian didasarkan atas relevansinya dengan studi sastra, khususnya resepsi yang difokuskan pada analisis teks-teks transformasi dari versi Wirjaatmadjan. Pada tahap ini diberlakukan pendekatan sastra dengan menganalisis secara struktural teks yang dilanjutkan dengan mencermati keberadaan teks-teks hasil transformasi di atas.

\section{HASIL DAN PEMBAHASAN}

\section{A. Keberadaan Babad Banyumas Versi Wirjaatmadjan}

Berdasarkan penelitian Priyadi (1997b) terdapat 10 naskah yang dapat digolongkan menjadi naskah-naskah yang memuat teks Babad Banyumas versi Wirjaatmadjan. Dalam penelitian ini, tampaknya dapat dicermati bahwa di antara 10 naskah tersebut menunjukkan karakteristiknya masing-masing sehingga dapat dikelompokkan menjadi tiga, yaitu (1) naskah yang berisi teks asli karya Wirjaatmadja yang terkandung dalam dua naskah (Babad Banyumas wiwit Kraton Majapahit dan Babad Banjumas wiwit Djaman Kraton Madjapahit). Kedua naskah merupakan koleksi Soedarmadji di Purwokerto. Naskah pertama adalah naskah setebal 67 halaman dengan kertas yang dipakai berukuran $16 \times 21 \mathrm{~cm}$. Naskah ditulis dalam huruf Jawa dan berbentuk prosa. Naskah ini diduga merupakan karya Wirjaatmadja yang sesungguhnya. Naskah kedua diketik pada kertas folio 24 halaman. Naskah ini adalah salinan yang dikerjakan oleh cucu Yoedosoebroto pada tahun 1992. Selanjutnya, naskah juga memberi keterangan bahwa naskah induk mulai ditulis pada 12 Juli 1955 oleh Patih Banjarnegara, Raden Yoedosoebroto dengan memakai naskah tulisan tangan Raden Arja Wirjaatmadja, Patih Purwokerto sebagai acuan penyalinan. Dengan demikian, naskah yang kedua ini menjelaskan proses penyalinan dari teks aslinya (karya Wirjaatmadja) oleh Patih Yoedosoebroto dan disusul oleh cucu Raden Yoedosoebroto; (2) naskah-naskah yang sudah mendapat campur tangan penyalin dan telah dicetak. Di sini, ada empat naskah, yakni Babad Banyumas 
wiwit Majapahit (koleksi Museum Sana Budaya, Yogyakarta), Babad Banjoemas (naskah cetak yang diterbitkan oleh Electrische Drukkerij TAN Poerbolinggo, tahun 1932), Babad Banjumas (salinan Adimulya), dan Babad Banyumas (salinan Raden Soemitro). Naskah yang pertama tergolong unik dengan memberi penjelasan proses penyalinan yang cukup panjang. Naskah yang tersimpan pada Museum Sana Budaya tersebut adalah milik Poerbodipoero. Naskah induk yang disalin adalah naskah milik Raden Mas Arya Sujanapura, Bupati Anom Urdinas di Surakarta oleh abdi dalem bekel carik kraton yang bernama Mas Bekel Wignyaukara. Pada bagian lain disebutkan bahwa Babad Banyumas tersebut merupakan karya Raden Arja Wirjaatmadja, Patih Purwokerto. Karya tersebut kemudian diterbitkan oleh Raden Salsaman dalam bahasa Jawa huruf Latin cetakan pertama dan dicetak oleh Setumdrikke Iman F. Mardimulya, Jogjakarta (Behrend 1990: 80, bdk. Pigeuad 1967: 147 \& 1968: 510). Jadi, naskah yang pertama ini ditulis dalam huruf Jawa, dicetak dalam huruf Latin, disalin kembali ke dalam huruf Jawa, dan disimpan di Museum Sana Budaya. Naskah yang kedua merupakan penerbitan lokal Purbalingga sehingga penyebarannya mencapai wilayah Karesidenan Banyumas. Naskah cetakan ini tergolong sangat populer di Banyumas sehingga orang yang tidak sempat atau tidak mampu membeli dapat menyalinnya. Naskah salinan Adimulya di Banjarnegara (naskah ketiga) dan Raden Soemitro di Purwokerto (naskah keempat) merupakan contoh kasus yang menarik untuk dicermati. Dari keempat naskah tersebut, karya Adimulya dan Soemitro mempunyai hubungan penyalinan langsung dengan naskah cetakan Purbalingga. Dalam teks cetakan Purbalingga terdapat campur tangan Patih Banyumas Raden Poerwasoepradja, sedangkan naskah yang diterbitkan oleh Salsaman masih sangat dekat dengan karya asli Wirjaatmadja yang ditulis dalam huruf Jawa; (3) naskah-naskah yang tergolong karya-karya transformasi dari teks karya Wirjaatmadja. Di sini, ada empat naskah, yakni Uittreksel uit de Babad Banjoemas, Babad Banjumas karya Oemarmadi dan Koesnadi Poerbosewojo, Riwayat Banyumas, dan Sejarah Kabupaten Banyumas. Naskah yang pertama adalah karya Patih Banyumas Poerwasoepradja dalam bahasa Belanda yang diselesaikan pada tanggal 15 Pebruari 1932 dan diterbitkan dalam bentuk pamflet dua halaman folio oleh Drukkerij Providence Poerwokerto pada tanggal 15 Maret 1932. Naskah kedua juga merupakan naskah cetakan yang berisi karya transformasi Oemarmadi dan Koesnadi Poerbosewojo (huruf Latin dan memakai bahasa Indonesia). Naskah yang diterbitkan di Jakarta pada 11 Maret 1964 ini memuat keterangan tanggal yang sama sebagaimana disebutkan dalam naskah cetakan Purbalingga tahun 1932, yakni tanggal 25 Oktober 1898 sebagai tanggal perintah Asisten Residen di Purwokerto, W.P.D. de Wolff van Westerrode. Menurut kedua penulis, naskah tertanggal 25-101898 adalah catatan-catatan leluhur yang perlu disusun kembali agar peristiwaperistiwanya runtut. Naskah ketiga merupakan hasil terjemahan ke dalam bahasa Indonesia oleh Adisarwono terhadap naskah cetakan Purbalingga dan diterbitkan oleh Tiga Serangkai pada tahun 1986, sedangkan naskah keempat adalah naskah hasil salinan oleh Sanmardja ke dalam huruf Jawa dan bahasa Jawa dari karya Oemarmadi dan Koesnadi Poerbosewojo (cetakan Latin dan bahasa Indonesia). Dengan demikian, naskah tulisan Jawa yang berisi teks asli karya Raden Arja Wirjaatmadja dijadikan teks variabel dan dikaji dengan mencermati teks yang terkandung dalam 
naskah salinan cucu Yoedosoebroto dan teks-teks transfromasinya.

\section{B. Terbitan Salsaman dan Terbitan Poerwasoepradja}

Terbitan Salsaman memuat kata pengantar yang berbeda dengan terbitan Poerwaosoepradja (terbitan Drukkerij TAN Poerbolinggo). Kata pengantar Salsaman menunjukkan bahwa Babad Banyumas karya Wirjaatmadja ini ditulis pada sekitar tahun 1896-1900 ketika W.P.D. de Wolff van Westerrode menjabat asisten residen di Purwokerto. Van Westerrode mempertanyakan awal-mula dari peristiwa perpindahan Kangjeng Raden Adipati Mertadiredja (bupati Purwokerto) ke Banyumas. Pada saat itu, Patih Wirjaatmadja menjelaskan sejarahnya sehingga asisten residen di Purwokerto itu memerintahkan sang patih untuk menulis babad leluhurnya. Selanjutnya, Salsaman memberi keterangan bahwa penulisan babad oleh Wirjaatmadja itu didasarkan atas naskah Babad Banyumas dalam bentuk tembang dan keterangan lisan yang diperoleh sang patih itu dari orang-orang tua yang hidup sezaman, atau peristiwa sejarah yang dialaminya sendiri. Dalam penyusunan kalimat dan pemilihan kata yang dipakai dalam babad, sang patih memperoleh bantuan dari Dwijasewaya, seorang mantri guru angka 1 di Purwokerto.

Pada bagian lain, Salsaman menuturkan bahwa perpindahan bupati Purwokerto ke Banyumas sudah menjadi legenda, yaitu ramalan Kiai Mranggi Semu di Kejawar yang menyatakan bahwa "besuk yen ana kudhi tarung karo karahe, negara Banyumas bali maring sing duwe." Ramalan ini benar-benar terjadi ketika De Clereq van Moolenburgh menjabat Residen Banyumas, sedangkan yang menjadi bupati Raden Mas Tumenggung Cakranegara II. Akibat perselisihan itu, sang bupati meminta mengundurkan diri pada tahun 1879. Pada akhirnya, Kangjeng Raden Adipati Mertadiredja III pindah menjadi bupati Banyumas.

Mencermati keterangan Salsaman di atas, agaknya ia tidak bisa membedakan antara keturunan Cakrawadana di Banyumas dengan yang ada di Cilacap. Oleh karena itu, ia menyebut Raden Mas Tumenggung Cakranegara II dengan nama Raden Mas Tumenggung Cakrawadana II. Dalam sejarah Banyumas, tidak ada bupati yang menggunakan nama nunggak semi dari Cakrawadana (Kasepuhan). Ada tiga orang bupati yang menjadi wedana bupati Kasepuhan, yaitu Kangjeng Raden Adipati Cakrawadana, Raden Tumenggung Cakranegara I, dan Raden Mas Tumenggung Cakranegara II. Pada bagian akhir, terdapat alasan Salsaman untuk menerbitkan naskah Wirjaatmadjan ini dan dijual kepada umum, yaitu agar orang-orang yang merasa dirinya keturunan Banyumas dapat memahami masa lampau atau sejarah nenek-moyangnya.

Berbeda dengan terbitan Salsaman, terbitan Poerwasoepradja menyatakan bahwa penulisan babad oleh Patih Purwokerto itu semata-mata hanyalah atas perintah asisten residen di Purwokerto, tanpa penjelasan lain seperti pada kata pengantar yang ditulis oleh Salsaman. Terbitan ini menyebut waktu perintah W.P.D. de Wolff van Westerrode, yaitu hari Selasa Wage 25 Oktober 1898 atau 9 Djoemadilakir 1828. Kata pengantar terbitan Poerwasoepradja menjadi ciri khas untuk membedakan antara penerbitan yang satu dengan penerbitan yang lain. Di samping itu, penerbitan Poerwasoepradja juga terdapat keterangan penutup yang menyudahi karya Raden Arja Wirjaatmadja dan keterangan Poerwasoepradja yang meneruskan karya Wirjaatmadja pada hari Minggu Kliwon, 21 Februari 1932. 
Dibandingkan dengan terbitan Poerwasoepradja, terbitan Salsaman hanya menyebut tiga angka tahun yang berkaitan dengan peristiwa Perang Dipanegara. Tiga angka tahun tersebut memang sudah ditulis oleh Patih Wirjaatmadja sendiri. Terbitan Poerwasoepradja memang banyak ditemukan angka-angka tahun yang berkaitan dengan peristiwa-peristiwa sejak keberadaan kerajaan Mataram yang dihubungkan dengan Banyumas. Tambahan angka-angka tahun pada karya Wirjaatmadja, khususnya terbitan Poerwasoepradja, yang menjadikan babad tersebut disebut sebagai 'babad baku' atau 'buku sejarah' oleh para pembaca. Namun, tidak semua angka tahun yang disajikan itu sesuai dengan kebenaran sejarah. Agaknya Poerwasoepradja hanya memperkirakan zaman atau periode tertentu pada kerajaan Jawa (Majapahit, Demak, Pajang, Mataram, Plered, Kartasura, Surakarta) dengan keberadaan kadipaten Wirasaba atau kabupaten Banyumas. Oleh karena itu, angka-angka tahun pada terbitan Poerwasoepradja tidak boleh dianggap sebagai keterangan yang pasti. Angka-angka tahun tersebut perlu dicermati dengan cara membandingkan dengan sumber-sumber lain, baik lokal Banyumas maupun lokal lain.

\section{Salinan Adimulya dan Soemitro}

Salinan Adimulya (tebal 27 halaman kuarto) dan Soemitro (tebal 59 halaman folio) jelas mengacu kepada terbitan Poerwasoepradja karena terdapat kata pengantar, pengantar penutup, dan keterangan karya lanjutan Poerwasoepradja yang sama. Rupanya Adimulya tidak selesai menyalin dari seluruh teks dan hanya sampai pada halaman 64. Halaman 65-69 tidak ditemukan, sedangkan Soemitro menyalin hingga akhir. Karya salinan mereka juga melestarikan angka-angka tahun pada terbitan Poerwasoepradja. Justru karena terbitan Poerwasoepradja dianggap sebagai 'buku sejarah,' maka penyalinan terhadap naskah itu berlangsung secara terus-menerus sehingga babad itu tersosialisasikan. Anggapan masyarakat bahwa suatu karya babad itu dianggap penting akan mendukung adanya penyalinan sepanjang masa. Namun, proses penyalinan seringkali menyebabkan adanya perubahan teks. Pada masa itu, teknologi percetakan sudah dikenal di Karesidenan Banyumas, khususnya di kota-kota kabupaten. Maka dari itu, karya Wirjaatmadja diterbitkan di Purbalingga pada tahun 1932. Karya babad yang dicetak memungkinkan naskah banyak dimiliki oleh warga masyarakat yang berminat dan mampu membelinya.

\section{Teks-Teks Transformasi}

\section{Uittreksel uit de Babad Banjoemas (UBB)}

UBB merupakan ringkasan dari karya Patih Wirjaatmadja yang dikerjakan oleh Poerwasoepradja di Banyumas pada tanggal 15 Pebruari 1932. Karya tersebut kemudian dicetak oleh Drukkerij 'Providence" Poerwokerto, tanggal 15 Maret 1932. Perlu diketahui bahwa pada tahun yang sama, Patih Poerwasoepradja juga menerbitkan Babad Banjoemas karya Wirjaatmadja pada penerbit Electrische Drukkerij "TAN" Poerbolinggo setelah ia memberi tambahan berupa karya lanjutan yang tertanggal 21 Pebruari 1932. Dengan demikian, kiprah Patih Banyumas Poerwasoepradja dalam dunia pernaskahan Banyumas, khususnya Babad Banjoemas versi Wirjaatmadjan menjadi semakin jelas.

UBB diciptakan oleh Poerwasoepradja berdasarkan karya Wirjaatmadja dengan memperhatikan silsilah para adipati atau bupati Wirasaba dan Banyumas. Hal itu dapat dipahami karena Babad Banjoemas terbitan Purbalingga di atas dibubuhi 
keterangan judul dan kata pengantar sebagai berikut, "Gantjaran Sadjarahhipoen Kaboepaten Banjoemas, tedak toemedak ngantos doemoegi ing sapoenika, namoeng kapendet saperloenipoen ingkang nedakaken Boepati-boepati kemawon..." Atas dasar inilah Poerwasoepradja membuat ringkasan. Ringkasan ini disusun mulai Raden Baribin hingga Kangjeng Raden Adipati Gondosoebroto. Semuanya ada 18 generasi. Silsilah 18 generasi itu sebenarnya merupakan kerangka teks Babad Banjoemas versi Wirjaatmadjan. Di sini Patih Banyumas Poerwasoepradja benar-benar konsisten. Artinya, ia hanya mengambil unsur teks yang diperlukan untuk menyusun ringkasan ini, yakni silsilah yang sangat sentralistik Wirasaba dan Banyumas. Di luar keduanya, Patih Poerwasoepradja mengabaikan unsurunsur naratif yang mencakup keberadaan Cilacap, Dayeuhluhur, Kartanagara, Kanduruwan, dll., karena tidak ada kaitan langsung dengan bupati-bupati. Keberadaan daerah tersebut di dalam Babad Banjoemas hadir karena adanya saudara bupati atau saudara sepupu bupati yang menjadi penguasa di situ.

Untuk lebih jelasnya, Poerwasoepradja membuat kerangka teks sebagai berikut : (1) Raden Baribin : adik raja Majapahit, dua buah pepali, dan perkawinannya dengan putri Pajajaran, (2) Raden Ketuhu (Wiro Utomo II), (3) Adipati Urang (Wiro Utomo III), (4) Adipati Surawin, (5) Joko Tambangan (Adipati Suro Utomo), (6) Bagus Wargo (Adipati Wargo Utomo I) dengan lima buah pepalinya, (7) Jaka Kaiman (Adipati Wargo Utomo II) dengan pembagian Wirasaba dan perpindahan ke Banyumas, (8) Ngabehi Janah (Mertosuro I), (9) Mertosuro II (Ngabehi Kaligetuk), (10) Tumenggung
Mertoyudo I, (11) Tumenggung Mertoyudo II (Mertonagoro atau Yudonegoro I atau Tumenggung Kokum atau Tumenggung Sedo Mesjid), (12) Tumenggung Yudonegoro II (Tumenggung Sedo Pendopo), (13) Bagus Mertawijaya (Pandji Gondokusumo atau Tumenggung Yudonegoro III atau K.R.Adipati Danuredjo I), (14) Tumenggung Yudonegoro IV, (15a) Tumenggung Yudonegoro V (Yudonegoro Longsor), (15b) Tumenggung Mertodiredjo I (Kangjeng Raden Adipati Brotodiningrat), (16) Tumenggung Brotodimedjo (K.R.A. Mertodiredjo II), (17) Raden Mertorejo (K.P.A. Mertodiredjo), dan (18) K.R.A.A. Gondosoebroto.

Unsur-unsur naratif melekat hanya pada tokoh tertentu saja, yakni Raden Baribin, Warga Utama I, Warga Utama II, Mertasura II, Tumenggung Mertayuda II, Tumenggung Yudanegara II, Bagus Mertawijaya, Yudanegara V, Mertadiredja I, Mertadiredja II, Mertadiredja III, dan Gandasubrata. Dalam menceritakan Bagus Mertawijaya, teks menyinggung saudara Mertawijaya yang menjadi penguasa di Purbalingga, yaitu Tumenggung Dipayuda I. Keberadaan Dipayuda I ini penting karena berkaitan dengan subjudul "Terug Tot" yang menjelaskan adanya empat tokoh yang memakai nama Dipayuda. Dipayuda II dan III bukan keturunan langsung Dipayuda I. Dipayuda II adalah putra Yudanegara III, sedangan Dipayuda III adalah anak Demang Arsantaka dari Panggendolan yang menjadi menantu Yudanegara III. Penjelasan mengenai keturunan Dipayuda I mengaitkan antara Banyumas dengan Purbalingga dan Banjarnegara. Cucu Dipayuda I adalah Dipayuda IV yang menjadi bupati Banjarnegara yang pertama setelah 
dibentuknya Karesidenan Banyumas. Trah Dipayuda I di Banjarnegara hanya dua generasi, yaitu Dipayuda IV dan Dipadiningrat. Setelah mereka, ada tiga orang bupati trah Kolopaking di Banjarnegara, yaitu Joyonegoro I, Joyonegoro II, dan Soemitro Kolopaking Poerbonegoro.

Unsur naratif lain yang cukup penting adalah menyangkut keberadaan Ngabehi Mertawijaya di Singasari yang tinggal di Kedungrandu, Patikraja. Ia adalah saudara Yudanegara IV yang akan menurunkan bupati Mertadiredja I, II, III, dan Gandasubrata. Munculnya trah Mertadiredjan karena dipecatnya Yudanegara V dari jabatan bupati Banyumas dan keturunannya tidak ada yang menggantikan kedudukkan ayahnya. Unsur-unsur naratif yang terkait dengan empat tokoh trah Mertadiredjan berisi kisah karir mereka dari bawah hingga akhir. Pada saat ringkasan ini ditulis, Gandasubrata belum mendapat gelar pangeran, tetapi masih bergelar adipati (Kangjeng Raden Adipati Aria Gandasubrata).

Pada bagian catatan teks terdapat keterangan mengenai Patih Banyumas, Raden Behi Sontodiredjo. Sontodiredjo adalah ayah penulis, Poerwasoepradja, yang meninggal dunia pada tanggal 11 Januari 1898. Ia adalah saudara laki-laki Kangjeng Raden Adipati Dipadiningrat (bupati Banjarnegara). Berarti mereka adalah putra Kangjeng Raden Tumenggung Dipayuda I, bupati Banjarnegara pertama (1831-1846). Selanjutnya, Raden Ayu Sontodiredjo adalah adik perempuan Kangjeng Pangeran Aria Mertadiredja III. Pada bagian akhir, disebut adanya pepali dari Kangjeng Raden Adipati Danuredja I yang menyatakan bahwa keturunan Dipayuda tidak boleh memakai pakaian serba wulung. Di sini, kata wulung diterjemahkan sarwo ireng, suatu terjemahan yang tidak tepat. Warna wulung seharusnya diterjemahkan dengan warna ungu atau keunguan.

2. Babad Banjumas Oemarmadi dan Koesnadi Poerbosewojo (BBOK)

BBOK diterbitkan dan diedarkan pada tahun 1964 oleh Amin Sujitno Djojosudarmo, Jalan Krakatau 13, Jakarta. Dalam teks terdapat empat ilustrasi lukisan dan satu peta yang disuguhkan oleh Imam Soemardi, yaitu (1) Kamandaka bertapa, (2) Pesarean Tjisagu (Sidaredja), (3) Gandek menghadap, (4) Tentara Kompeni Belanda, dan (5) peta karesidenan Banyumas.

Pada kata pengantar kedua penulisnya menyatakan bahwa teks disusun berdasarkan catatan leluhur yang sudah berusia 68 (seharusnya 66) tahun, yaitu sejak tahun 1898 sampai 1964. Yang menarik adalah kata pengantar itu menyebut tanggal catatan, yakni 25 Oktober 1898. Tanggal tersebut dalam Babad Banjoemas versi Wirjaatmadjan (khususnya yang sudah dicetak) adalah tanggal perintah dari Asisten Residen Purwokerto, W.P.D. de Wolff van Westerrode. Berdasarkan tanggal tersebut dapat disimpulkan bahwa BBOK adalah karya transformasi Babad Banjoemas versi Wirjaatmadjan (selanjutnya disingkat BBW).

Kedua penulis BBOK membagi teks menjadi 42 bagian sebagai berikut : (1) Letaknya, (2) keadaan tanahnya, (3) Bahasanya, (4) Sungainya, Pegunungan Dieng, (6) Pulau Nusa Kambangan, (7) Bunga Wijayakausuma, (8) Desa Pasiraman, (9) Pasirluhur, (10) Pesaren Cisagu, (11) Pesarean Syekh Jambukarang, (12) Perjuangan, (13) Raden Baribin, (14) Kerajaan Pajajaran, (15) Kabupaten Wirasaba, (16) Adipati Marapat, (17) Kabupaten Banyumas, (18) Tumenggung Seda Pendapa, (19) Perang Mangkubumen, (20) Perang di Jenar, (21) 
Kangjeng Raden Adipati Danuredja, (22) Kabupaten Banyumas dibagi Menjadi Dua, (23) Pembagian Daerah Kabupaten Kanoman dan Kasepuhan,

Kabupaten Purbalingga, (25) Benteng Cilacap, (26) Kabupaten Adipala dipasukan, (27) Kewajiban para Bupati dalam Zaman Perang Dipanagara, (28) Pertempuran di Purworejo (dekat Kelampok), (29) pertempuran di Widarapayung, (30) Kabupaten Majenang, (31) Meneruskan Perang Dipanagaran, (32) Hadiah setelah Peperangan Dipanagaran Berhenti, (33) Pembagian Daerah Kabupaten, (34) Kabupaten Purwokerto, (35) Susunan Para Bupati Banyumas seluruhnya, (36) Kabupaten Banjarnegara, (37) Berdirinya Kabupaten Cilacap, (38) Riwayat Pendapa Kabupaten Banyumas yang bernama Si Panji, (39) Lalu Lintas, (40) Raja Jembrana (Bali), (41) Ramalan dari para Sepuh, (42) Penutup.

Bagian (1) sampai (12) dan (42) merupakan tambahan kedua penulis teks, sedangkan bagian (40) dan (41) bukan karya Wirjaatmadja. Kemungkinan diambil dari karya lanjutan Patih Banyumas, Poerwasoepradja. Bagian (1) hingga (12) berisi legenda-legenda yang hidup dalam masyarakat Banyumas. Agaknya keduabelas bagian itu merupakan pengantar menuju Babad Banyumas, khususnya bagi orang-orang Banyumas yang sudah tidak mengenal lagi legenda nenek-moyangnya. Jadi, isi teks BBW terdapat pada bagian (13) sampai (39). Bagian (34), (35), (36), dan (37) yang berisi catatan para bupati dari Kabupaten Purwokerto, Banyumas, Banjarnegara, dan Cilacap tampaknya disusun atas pengetahuan kedua penulis karena BBW tidak menyebut seluruh bupati dari masing-masing kabupaten pada teksnya.
Satu hal perlu dicermati adalah bahwa teks BBOK seperti halnya BBW menyebut hanya empat orang bupati Banyumas yang bergelar Yudanegara. Padahal, seharusnya ada lima orang. Hilangnya satu orang Yudanegara itu dimulai dari kesalahan bahwa putra Mertonegoro adalah Yudanegara I, seharusnya Mertonegoro sama dengan Yudanegara I. Dalam teks-teks Babad Banyumas yang lain, Mertonegoro mempunyai nama lain yang cukup banyak, yakni (1) Tumenggung Mertayuda II, (2) Tumenggung Kokum, (3) Tumenggung Todan,

Tumenggung Seda Mesjid, dan (5) Yudanegara I. Berpangkal dari identifikasi nama tersebut, maka akan teridentifikasi pula empat orang Yudanegara yang lain. Kekurangcermatan dalam penyalinan teks sebenarnya sudah dimulai dari Babad Banyumas versi Banjarnegara yang masih dalam bentuk tembang macapat. Persoalan ini pernah dibicarakan dalam penelitian dan pembahasan yang lalu (lihat Priyadi 2002: 132-133). Dengan demikian, telah terjadi penyimpangan beruntun pada persoalan Yudanegara dari teks Babad Banyumas versi Banjarnegara (tembang macapat), Babad Banjoemas versi Wirjaatmadjan (BBW, gancaran), dan Babad Banjumas Oemarmadi dan Koesnadi Poerbosewojo (BBOK).

\section{Riwayat Banyumas (RB)}

RB adalah teks cetakan Tiga Serangkai, Solo, 1986. RB merupakan hasil terjemahan dari bahasa Jawa ke dalam bahasa Indonesia oleh $S$. Adisarwono terhadap karya Patih Wirjaatmadja yang sudah dicetak oleh Electrische Drukkerij "TAN" Poerbolinggo pada tahun 1932. Seperti halnya Oemarmadi dan Koesnadi, tampaknya Adisarwono juga membagi 
teks BBW agar mudah dalam memahami dan meruntutkan kisah sejarah Banyumas: (1) Raden Baribin, (2) Adipati Wargautama I yang malang, (3) yang malang di Hari Sabtu Pahing, (4) Kabupaten Wirasaba dibagi Empat, (5) Kabupaten Banyumas, (6) Perlawanan Kanjeng Pangeran Mangkubumi dan Kanjeng Pangeran Mangkunegoro Melawan Kompeni, (7) R. Tumenggung Cakrawadana, (8) Kabupaten Purbolinggo, (9) Kerusuhan di Muara Donan, (10) Kabupaten Banyumas dipecah Menjadi Dua Bagian, (11) Kabupaten Dayahluhur, (12) Banyumas Menjadi Medan Perang Diponegoro, (13) Siasat Licik jenderal De Kock, (14) Kabupaten Purbolinggo, (15) Kabupaten Purwokerto, (16) Kabupaten Cilacap, (17) Kabupaten Banjarnegara, (18) Kabupaten Karanganyar, (19) Banyumas di sekitar tahun 1931, (20) Selayang Pandang Pemerintahan Kabupaten Daerah Tingkat II Banyumas, (21) Penutup, (22) Latar Belakang Sejarah, (23) Proses Pembentukan, (24) Tata Pemerintahan, dan (25) Keadaan Wilayah.

Bagian (21) hingga (25) tampak jelas sebagai tambahan penerjemah. Pada bagian (21) penerjemah mencoba menyimpulkan isi BBW dengan menonjolkan kota Purwokerto sebagai ibu kota Kabupaten Banyumas sekarang ini. Kemudian, ia menarik ke belakang dengan kisah legendaris Sungai Serayu dan Kayu Mas yang dijadikan saka guru Pendapa Si Panji pada masa Adipati Warga Utama II atau Adipati Mrapat. Di sini, penerjemah melakukan anakronisme. Pendapa Si Panji tidak dibangun pada masa Adipati Mrapat, tetapi pada masa Tumenggung Yudanegara II yang terkenal dengan sebutan Tumenggung Seda Pendapa. Nama Si Panji diambil dari nama putranya yang bernama Raden Panji Gandakusuma yang di kemudian hari bakal menggantikan kedudukan ayahnya dengan gelar Tumenggung Yudanegara III. Di samping itu, tampaknya penerjemah juga memberi informasi yang menyesatkan bahwa tahun 1582 merupakan tonggak berkuasanya Adipati Mrapat. Persoalan ini telah dibahas secara mendalam oleh Priyadi (2001).

Selanjutnya, penerjemah menyusun urutan bupati Banyumas yang pernah berkuasa dari awal (Adipati Mrapat) hingga akhir (R.G. Roedjito). Di sini, Sudjiman Mertadiredja Gandasubrata ditulis dua kali, seharusnya bupati sebelumnya adalah Kangjeng Pangeran Aria Gandasubrata. Pada bagian ini ada sebuah foto bupati (R.G. Roedjito) dan empat lukisan wajah bupati Banyumas (Sudjiman Mertadiredja Gandasubrata, Raden Moch. Kaboel Poerwodirdjo, Raden Soebagijo, dan Poedjadi Djaring Bandajuda). Lukisan wajah bupati juga ditemukan pada bagian (13), yaitu lukisan Kangjeng Pangeran Aria Mertadiredja III dan Kangjeng Pangeran Aria Gandasubrata. Lukisan-lukisan wajah bupati yang dimuat dalam naskah cetakan ini berasal dari lukisan yang terdapat pada ruang salon Kabupaten Banyumas di Purwokerto.

Bagian (22) sampai (25) berisi mengenai sejarah berdirinya kota administratif Purwokerto dan perkembangannya. Empat bagian terakhir ini membicarakan sejarah kontemporer Banyumas, khususnya kota Purwokerto sebagai ibu kota Kabupaten Banyumas yang ditingkatkan menjadi kota administratif dan diresmikan pada tanggal 15 Januari 1983.

Selanjutnya, hasil terjemahan Adisarwono akan dicermati berdasarkan teks BBW. Terjemahan Adisarwono terhadap BBW memang sering disertai penafsiran yang terlalu larut dengan teks yang mengakibatkan karya Wirjaatmadja 
menjadi semakin jauh dari teks aslinya. Penafsiran Adisarwono itu tampak pada (1) pencitraan Raden Baribin yang terlalu ideal, (2) hubungan antara Raden Baribin dengan Ki Gede Ngayah, (3) keadaan kota Wirasaba dan sekitarnya pada abad ke-XV, (4) keruntuhan Majapahit dengan candra sengkala 'sirna ilang kertaning bumi,' (5) membuat cerita rekaan Demang Toyareka, (6) penokohan yang keliru (putri Wirasaba diberi nama Rara Sukesi dan anak Demang Toyareka diberi nama Mangun), (7) perjalanan pulang Adipati Warga Utama I, (8) Pengkeramatan makam Adipati Warga Utama I, (9) pernyataan Banyumas didirikan pada tahun 1582, (10) membuat cerita legendaris kayu mas, kesalahan jumlah bupati yang memakai nama Yudanegara, (12) komentar tentang perang Dipanegara, (13) memakai sumber naskah cetak Uittreksel uit de Babad Banjoemas (UBB), dan (14) menerjemahkan juga karya lanjutan Patih Poerwasoepradja.

\section{Sejarah Kabupaten Banyumas (SKB)}

SKB adalah naskah Jawa setebal 29 halaman (kertas ukuran $21 \times 16 \mathrm{~cm}$ ) yang ditulis oleh Tukang Uang Desa Kalisube, Kecamatan Banyumas, Sanmardja. Sanmardja agaknya menerjemahkan BBOK dari bahasa Indonesia ke dalam bahasa Jawa, dan selanjutnya ditulis kembali dengan huruf Jawa. Namun, terjemahan Sanmardja tidak menyeluruh, tetapi terbatas pada bagian (17). Bagianbagian lain disingkat sehingga teks SKB merupakan ringkasan dari BBOK. Pada intinya teks SKB berisi (1) urutan bupati dari Adipati Mrapat sampai Yudanegara I, (2) kisah Tumenggung Mertanegara, (3) kisah Tumenggung Toyakusuma, (4) kisah Kaligawe, (5) kisah lokal tentang Selandaka, (6) Geger Pacina, (7) kisah meninggalnya Ngabehi Mertawijaya di Kedungrandu, (8) Banyumas dibagi dua,
(9) Perang Dipanegara, dan (10) silsilah Kiai Mranggi Kejawar.

Sanmardja dalam proses penerjemahan, penyingkatan, dan penulisan kembali dengan huruf Jawa tetap mengikuti kesalahan bersama pada masalah yang sama dengan BBW dan BBOK, yaitu jumlah bupati Banyumas yang memakai nama Yudanegara. Teks SKB pun tidak jelas dalam mengidentifikasikan tokoh-tokoh Yudanegara.

Sanmardja memberi tambahan teksteks yang bersifat lokal, yaitu kekeramatan petilasan di desa Selandaka, Kecamatan Sumpiuh. Selandaka hadir dalam teks ini karena salah seorang istri Yudanegara II berasal dari desa tersebut. Di situ, ada empat buah pusaka peninggalan Yudanegara II, yaitu (1) Payung Tunggul Naga, (2) Tumbak Si Kalang, (3) Klambi Antakesuma, dan (4) cemeti jaran dhawuk.

Teks tambahan yang lain adalah silsilah Mranggi Kejawar. Silsilah tokoh lokal di desa Kejawar, Banyumas memang tidak lagi ditemukan karena yang menjadi landasan penyusunan silsilah ini berasal dari teks Sejarah Yudanegaran (kemungkinan adalah teks Tedhakan Serat Soedjarah Joedanagaran) (lihat Priyadi 2002: 143). Silsilah Mranggi ini berkaitan dengan silsilah Bani Asim dari (1) Jaenal Ngabidin, (2) Sarif Imam Muhammad Barik, (3) Sayiddin Syekh Imam Muhammad Bakir, (4) Sarif Rukhanayah Imam Jafar (Sultan Rukhaniyah Arifin), (5) Syekh Sayid Muhammad Ghozali, (6) Syekh Ngaribi Sayiddin Ngestu Kutub Abi Khusni Karuni, (7) Syekh Sayid Ngudukhuli, (8) Sayiddin Imam Muhammad Ngasiki, (9) Sayiddin Ngarik, (10) Sayid Kahat, (11) Sayid Samud, (12) Wabaridik, (13) Sayid Lamasaad, (14) Sayid Alab Sidik, (15) 
Sayid Mutrahil Maulana Maghribi (Sultan sarif Maghribi), (16) Sayid Mudakir (Susuhunan Atas Angin), (17) Sultan Yaidubin Atas Abu Nakit Akbar, (18) Kangjeng Sunan Modang, (19) seorang wanita yang kawin dengan Pangeran Pujangga, (20) Ki Gede Buwara, (21) Ki Buyut Buwara, (22) Ki Buyut Susanda, (23) Ki Buyut Suwaba, (24) Ki Buyut Satmaka (Ki Mranggi Kejawar), (25) Sambarta (Ki Mranggi Semu atau Mranggi Ngenyawar) (Priyadi 2003: 432).

Tambahan yang lain adalah informasi adanya makam Tengku Ceh atau Tengku Aceh di desa Kejawar. Sanmardja agaknya memperoleh cerita lokal ini dari juru kunci makam tersebut, yaitu Wiryadimeja. Tengku Aceh tidak jelas identifikasi namanya. Menurut Juru kunci, Tengku Aceh adalah orang buangan, yaitu pembrontak yang tertangkap dan diasingkan di situ. Rupanya, Kejawar sejak dahulu merupakan daerah buangan, misalnya Raja Jembrana (Bali), Ngurah Made Pasekan beserta keluarganya pada tahun 1866 diasingkan di Karangpucung Kejawar. Salah seorang putranya yang bernama Gusti Nyoman Mas pernah menjadi wedana di Sokaraja. Makam Ngurah Made Pasekan dikenal masyarakat dengan Makam Raja Bali.

\section{KESIMPULAN}

Babad Banjoemas versi Wirjaatmadjan (BBW) pada hakikatnya dapat dibagi menjadi tiga, yaitu (1) naskah-naskah yang berisi teks asli karya Wirjaatmdja (ada dua naskah: Babad Banyumas wiwit Kraton Majapahit dan Babad Banjumas wiwit Djaman Kraton Madjapahit), (2) naskahnaskah yang sudah mendapat campur tangan penyalin dan telah dicetak (ada empat naskah: naskah koleksi Museum Sana Budaya, naskah terbitan Electrische
Drukkerij TAN Poerbolinggo, naskah Adimulya, dan naskah Soemitro), (3) naskah-naskah yang tergolong karyakarya transformasi dari teks karya Wirjaatmadja (ada empat naskah: Uittreksel uit de Babad Banjoemas, Babad Banjumas Oemarmadi dan Koesnadi Poerbosewojo, Riwayat Banyumas, dan Sejarah Kabupaten Banyumas).

Teks-teks transformasi dari Babad Banjoemas versi Wirjaatmadjan (BBW) ada empat: (1) Uittreksel uit de Babad Banjoemas (UBB) merupakan hasil ringkasan dari BBW dengan membuat urutan 18 adipati atau bupati Wirasaba atau Banyumas dari Raden Baribin sampai dengan Kangjeng Raden Tumenggung Gandasubrata; (2) Babad Banjumas Oemarmadi dan Koesnadi Poerbosewojo (BBOK) merupkan catatan yang berasal dari BBW. Teks BBOK dan BBW menyebut 4 orang bupati yang bernama Yudanegara; (3) Riwayat Banyumas (RB) merupakan terjemahan ke dalam bahasa Indonesia dari bahasa Jawa. RB banyak memasukkan legenda lokal, yaitu Sungai Serayu, kayu mas, dan menyusun bupati dari awal (Adipati Mrapat) hingga akhir (R.G. Roedjito); (4) Sejarah Kabupaten Banyumas (SKB) di samping menerjemahkan dari bahasa Indonesia ke dalam bahasa Jawa, bahkan ditulis kembali dengan huruf Jawa, juga menambahkan kekeramatan pusakapusaka dari desa Selandaka, menyusun silsilah Mranggi Kejawar berdasarkan Tedhakan Serat Soedjarah Joedanagaran, dan kisah Tengku Aceh di Kejawar.

\section{DAFTAR PUSTAKA}

Abdullah, Taufik. 1985. Sejarah Lokal di Indonesia. Yogyakarta: Gadjah Mada University Press.

Behrend, T. E., 1990. Katalog Induk Naskah-Naskah Nusantara, Jilid 1, 
Museum Sana Budaya Yogyakarta. Jakarta : Djambatan.

Behrend, T. E. \& Titik Pudjiastuti. 1997. Katalog Induk Naskah-Naskah Nusantara, Jilid 3-B, Fakultas Sastra, Universitas Indonesia. Jakarta: Yayasan Obor IndonesiaEFEO.

Culler, Jonathan. 1981. The Pursuit of Signs, Semiotics, Literature, Deconstruction. London \& Henley: Routledge \& Kegan Paul.

De Graaf, H. J. 1985. Awal Kebangkitan Mataram. Jakarta: Grafitipers.

Eagleton, Terry. 1988. Teori Kesusasteraan. Kuala Lumpur: Dewan Bahasa dan Pustaka Kementrian Pendidikan Malaysia.

Knebel, J. 1901. "Babad Banjoemas, Volgens een Banjoemaasch Handschrift beschreven." Tijdschrift van het Koninklijk Bataviaasch Genootschap van Kunsten en Wetenschappen, deel XLIII: 397-443.

Pigeaud, Th. G. Th. 1967. Literature of Java, Volume I. The Hague: Martinus Nijhoff

Pigeaud, Th. G. Th. 1968. Literature of Java, Volume II. The Hague: Martinus Nijhoff.

Pigeaud, Th. G. Th. \& H. J. de Graaf, 1985. Kerajaan-kerajaan Islam di Jawa. Jakarta: Grafitipers.

Priyadi, Sugeng. 1990. “Tinjauan Awal tentang Serat Babad Banyumas sebagai Sumber Sejarah." Seminar Sejarah Nasional V. Semarang: Jarahnitra, Direktorat Jenderal Kebudayaan, Depdikbud.

Priyadi, Sugeng. 1993. "Hubungan Sunda dan Tradisi Penulisan Babad di Daerah Banyumas." Makalah Simposium Internasional Ilmuilmu Humaniora II. Yogyakarta:
Fakultas Sastra Universitas Gadjah Mada.

Priyadi, Sugeng. 1996. "Sejarah Pangiwa dalam Tedhakan Serat Babad Banyumas." Dalam Kebudayaan No. 10: 63-67. Jakarta: Departemen Pendidikan dan Kebudayaan.

Priyadi, Sugeng. 1997a. "Sejarah Penulisan Babad Banyumas." Lembaran Sastra No. 23: 229-237. Semarang: Fakultas Sastra Universitas Diponegoro.

Priyadi, Sugeng. 1997b. “Babad Banyumas Versi Wirjaatmadjan: Fungsi dan Intertekstual." Laporan Penelitian. Purwokerto: Universitas Muhammadiyah Purwokerto.

Priyadi, Sugeng. 2000a. "Tedhakan Serat Babad Banyumas: Suntingan Teks, Terjemahan, dan Fungsi Genealogi dalam Kerangka Struktur Naratif." Laporan Penelitian. Purwokerto: Universitas Muhammadiyah Purwokerto.

Priyadi, Sugeng. 2000b. "Fenomena Kebudayaan yang Tercermin dari Dialek Banyumasan." dalam Humaniora, No.1. Yogyakarta: Fakultas Sastra Universitas Gadjah Mada.

Priyadi, Sugeng. 2001. Tinjauan Ulang Hari Jadi Kabupaten Banyumas. Yogyakarta: Kaliwangi Ofsset.

Priyadi, Sugeng. 2002. Banyumas: Antara Jawa dan Sunda. Semarang: Penerbit Mimbar-The Ford Foundation-Yayasan Adikarya Ikapi.

Priyadi, Sugeng. 2003. "Babad Banyumas: Hubungan Banyumas dengan Majapahit," dalam Prasasti, Volume 51, Th. XIII, edisi November. Surabaya: Fakultas Bahasa dan Seni, Universitas Negeri Surabaya. 


\section{Jurnal}

Sulastin-Sutrisno, 1994. "Teori Filologi dan

Penerapannya." dalam Siti Baroroh

Baried, dkk. Pengantar Teori

Filologi. Yogyakarta: BPPF

Fakultas Sastra Universitas Gadjah Mada.

Teeuw, A. 1988. Sastra dan Ilmu Sastra, Pengantar Teori Sastra. Jakarta: Pustaka Jaya-Girirmukti Pasaka.

Wiryamartana, I Kuntara, 1990. Arjunawiwaha Transformasi Teks Jawa Kuna Lewat Tanggapan dan Penciptaan di Lingkungan Sastra Jawa. Yogyakarta: Duta Wecana University Press. 